\title{
The Practice of Reading Approaches in Developing Students' Reading Competency on Javanese Language among Primary School Teachers
}

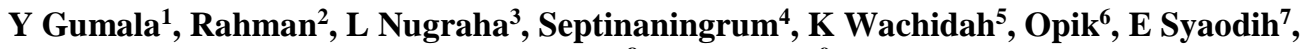 \\ F Ahmadi ${ }^{8}$, H Farhana9 \\ \{1 ${ }^{1}$ yosigumala@student.upi.edu, ${ }^{2}$ rahmanprofupi@upi.edu, ${ }^{3}$ lukmanmifdha82@ gmail.com \\ 4ningrumseptina@gmail.com, ${ }^{5}$ kemilwachidah@umsida.ac.id, ${ }^{6}$ gerimisculamega@yahoo.co.id, \\ ${ }^{7}$ ernawulansyaodih@upi.edu, ${ }^{8}$ ahmadi@ mail.unnes.ac.id, ${ }^{9}$ husna.farhana@dsn.ubharajaya.ac.id \} \\ ${ }^{1,9}$ Universitas Bhayangkara Jakarta Raya, Indonesia \\ ${ }^{2,6,7}$ Universitas Pendidikan Indonesia, Indonesia \\ ${ }^{3}$ STAI Miftahul Huda Subang, Indonesia \\ ${ }^{4}$ IAIN Tulungagung, Indonesia \\ ${ }^{5}$ Universitas Muhammadiyah Sidoarjo, Indonesia \\ ${ }^{8}$ Universitas Negeri Semarang, Indonesia
}

\begin{abstract}
Reading is important to students' academic achievement and contains a problematical process. One important aspect of teaching reading has been ignored, that is the need to teach students the suitable reading approaches. In this study we investigated the use of reading approaches in developing students' reading competency on Javanese language among primary school teachers. For the purpose of the study, twenty school teachers from jepara central java have been randomly selected as the research subjects. A questionnaire survey was administered to define whether the teachers have knowledge of reading approaches and to demonstrate their students. The findings of the study indicated that while teachers were responsive of the use of reading strategies in developing reading capabilities on javanese language, they did not completely utilized them in teaching reading to primary school students. Effective reading approaches such as setting context, recitation the text to students and predicting or interpreting transcript were less frequently used. Other than, teachers also unsecsessful to encourage students' interaction with the script.
\end{abstract}

Keywords: Reading Approach., Reading Competency, Javanese language.

\section{INTRODUCTION}

Reading is important to students' theoretical accomplishment and comprises a complex progression [1]. State that disappointment to acquire reading through principal level possibly will origin a learner to be missing in the capacity to read properly. Additionally, learners with imperfect literateness abilities could advance deprived self-respect, deficiency enthusiasm, presentation interactive and imaginary complications; consequently primary them to be separate commencing systematic national curriculum[2] .

In traditional Javaness Language classroom, reading is the most emphasized skill. This emphasis is necessary considering that reading is not a skill that can be automatically learned. 
Rather it involves a complex process of making meaning from a text for variety of purposes and in a wide range of contexts [3][4]. In Indonesia, emphasis is given by the Ministry of Education in trying to develop reading skills in Javaness Language especially among the primary students. This can be seen through the introduction of reading programmes such as 'The Structured Early Reading Programme' which aims to inculcate a love for reading at a young age. Schools are given 'big books' to be used with students through an extensive induction programme[5]. Presently, there is also a move to include the literature component in Javaness, Primary School Javaness Syllabus as a further effort to instil positive reading habits among the young school-children [6].

Conversely, one significant characteristic of teaching reading has been disregarded, that is the want to explain learners the suitable reading schemes [7]. Faster examination of the Primary School Syllabus Description exposes that the reading abilities toward be skilled such as conversation occurrence skills and reading for key concepts were identified. Not at all discussion was completed of the reading approaches that learners should be through awake of in increasing their reading capability. The prerequisite to teach reading approaches clearly is not specified as one of the chosen consequence of the national curriculum [8] .

In such a situation, the concern reductions on the take on of the teachers to teach learners roughly reading approaches and by what method to develop them [9]. To afford knowledge, teachers had better encouragement learners in considerate and exhausting reading approaches[10]. It is the teacher who requisite announce and deliver implementation in with reading approaches for managing with writings in an unaccustomed language. The request is ensure the primary school teachers in the nation explain reading approaches to their learners? Most essentially, are they attentive of the requirement to prepare so?

\section{RESEACH METHOD}

The perseverance of this education was to examine if educators are by means of reading approaches in the teaching space. A quantitative study was showed applying a feedback form survey method. The questionnaire is distributed interested in three measures. The main part apprehensions with material about the teacher's background. The second part of the survey is created with the determination of considering whether the educators are responsive of reading approaches and details why they feel teaching reading strategies is necessary. The next part purposes to consider whether they show reading approaches to the learners and to categorize their chosen reading approaches. For the examination determinations, sixty primary school Javanese teachers from Jepara Indonesia were accidentally a miscellany of as the examination subjects.

\section{RESULT AND DISCUSSION}

The first measure of the survey was considered for the persistence of prompting statistics on the accused experience. The board further down exemplified the analysis of defendants in period of gender. As can be assumed, the widely held of the accused $(68.3 \%)$ are female although only $31.7 \%$ of the defendants are male. This replicates the male: female teacher's percentage in schools in the nation. 
Table 1. Respondents by Gender

\begin{tabular}{ccc}
\hline Gender & Frequency & Percent \\
\hline Male & 23 & $31.7 \%$ \\
female & 27 & $68.3 \%$ \\
Total & 60 & $100 \%$ \\
\hline
\end{tabular}

The Chi-square test marks for the requests were all establish to be important at the equal of $\mathrm{p}<.01$. Permitting to these consequences, it be capable to be supposed that teaching in prereading strategies is used by the teacher but the used varies in term of frequency. The common of the teachers $(75 \%)$ frequently enquire the learners to read the script previously liability any argument. Further prevalent pre- reading approach charity is background commitments beforehand reading. $62 \%$ of the defendants indicate each 'always' or 'usually' as pointer for the usage of the approach. Most teachers warming up up questions (this is showed by $65.7 \%$ of the defendants who elected whichever 'always' or 'usually' designed for this possibility). Instruction expressions, enquiring learners to deliver the designations and to expression at design are commonly developed by individual quasi- of the teachers measured (at 50\%, 55\% and $75 \%$ separately). Pre- understanding assistances such as involving matter to practice, observing above the text hurriedly and scenery perspective are a lesser amount of widespread (normally employed by individual $40 \%$ of the accused for the main approach and by $55 \%$ of the defendants for the latter two approaches). The slightest widespread pre- understanding approach is by means of encouragements or symbols of office to set situation as specified by the trifling amount (30\%) of accused who marked 'usually' and 'always' for the decision. In assumption it be able to be supposed that, teachers prepare variety procedure of pre-reading approaches but the procedure of these pre- reading approaches are not common and the teachers ensure not effusively operates these pre- reading abilities in teaching [11].

The succeeding is a gradient of interrogations specified at what time directing study on Javanese literacy.

F1. I usual a persistence for reading and understanding.

F2. I question learners to delivered the designations and expect anything the transcript is roughly.

F3. I question learners to appearance at depictions and effort to speculation by what means they communicate to the transcript.

F4. I established a background previously learners activate reading.

F5. I procedure instructional assistances to customary a background.

F6. I consume the learners hurriedly appearance completed the transcript previously reading.

F7. I ask learners preparation requests allied to the transcript previously reading.

F8. I communicate words previously learners read the edition.

F9. Previously performance thoughts or several additional commotion, I take learners read the transcript.

F10. I inquire learners to communicate the edition/matter to their understanding.

F11. I question learners to transmit what they carried to what they straight now distinguish.

F12. I predictable a elasticity border for reading in dated.

F13. I communicate finally the innovative language in the handwriting.

F14. I inquire learners to procedure monolingual vocabulary.

F15. I tolerate learners to practice a fluent thesaurus.

F16. I communicate learners by what method to predict the denotation of unidentified arguments. 
F17. I enquire learners to presumption/forecast the significance of indefinite disputes

F18. I communicate the students to skip unknown disputes.

F19. I question learners to feature strange confrontations.

F20. I examine learners to feature key difference of opinion and/or expressions.

F21. I enquire learners to takings transcripts while understanding.

F22. I communicate learners to deliver wisely and gradually.

F23. I pressure the position of understanding every single term.

F24. I question learners to deliver the writing added than the minute.

F25. I examine learners to effort to envision whatever they read.

F26. I communicate learners to variety suppositions about up-coming material in the script.

F27. I partake learners deliver verbally in period one at a period.

F28. I show learners to deliver the major and last passages more wisely.

Allowing for these results, we can accomplish that though reading approaches are useful in the understanding commands with some approaches existence further widespread than others. The consequences demonstration that the most common reading approaches are learning the new words (laboring frequently or continually by $70 \%$ of defendants), inquiring learners to emphasize unidentified words (regularly or constantly castoff by $68 \%$ of defendants) and interrogative the learners to distributed the lettering gradually ( $72 \%$ of accused runs this attitude). It terminologies that the teachers inhabitance distinction on caring philological intelligence afterwards they interconnect reading to their novices. Specific of the impress methods which are generally hired by merely curved $56 \%$ of respondents are background period boundary, enquiring learners to categorize keyword, inquiring learners to deliver the typescript supplementary than as presently as and to envisage of any kind they transported[12]. This is dispiriting temporarily certain of these approaches have been found to be effective and educators should apply communicate the students to practice them in their understanding directions. Fewer general approaches are phrasebook usage, predicting sense of words, expecting, note captivating and by means of contextual information. Skipping unidentified arguments are the smallest general approach, actuality regularly cast-off by single $25 \%$ of the inhabitants. Henceforth, it be able to suppose that teachers' desertion teaching selected of the significant whereas reading approaches that can essentially benefit the learners developed improved learners or readers[13].

Starting the consequence it be able to be realized that the greatest prevalent post-reading approach is asking learners to response conception questions[14], undoubtedly subsequently most writing paperwork deliver conception enquiries for learners to exertion on. $80 \%$ of defendants selected this decision surveyed by conferring the writing and follow-up happenings (by $70 \%$ and $74 \%$ of the defendants correspondingly). Another time active post-reading strategies such as asking the students to comment and the text and summarizing the text are derelict by teachers. Slightest general approach is questioning the learners and questioning them to deduce the transcript. (Regularly charity by single $38 \%$ and $35 \%$ of the defendants correspondingly) This confirmations that most instructors do not income the exertion to variety the learners attentive of supplementary reading approaches that can be applied to assistance the learners develop their reading abilities[15].

\section{CONCLUSIONS}

In assumption it know how to be believed that teachers in primary school ensure partake the information of reading approaches. They organize clarify reading approaches to the learner 
to selected range but the grade of occurrence of usage is fairly inadequate. The teachers be likely to to emphasis on the similar reading approaches in lesson such as setting determination of reading, functioning on empathetic importance of words and responsibility understanding implementation. Further actual reading approaches such as background situation, connecting the script to learners' schemes and calculating or construing text are less regularly used. Importance is assumed on considerate the verbal importance of scripts but not so considerable on thoughtful related implication of the typescripts. Teachers correspondingly nosedive to reassure students' teamwork with the edition once they miscarry to utilize the directly above stated assistances. It is the educator tasks to sequence learners to define their particular objectives and approaches and in what way to practice all these approaches allowing to their intensities, comforts, and requests. Teachers consumed improved afford categorical lessons about mutually assistances and approaches. Training these categories of reading approaches obviously supports families to comprehend whatever they are responsibility and why it is imperative. Workspace and passages ought to be showed particularly for the educators who are not actual accustomed with the perception of reading approaches. Concluded works, teachers strength be learned about the perception of reading approaches, changed approaches and in what way to sequence learners on those approaches. Moreover, obvious directions, more clarifications or why to use convinced approaches have to be assumed to them. Teaching reading approaches ought to remain specified importance not individual by the instructors nevertheless similarly by programed developers and writing book journalists since it is actual valuable in serving the learners converted self-regulating learners. It is imperative to provide them through needed approaches and assistances so that they container stay operative learners.

\section{REFERENCES}

[1] A. M. Ermekbaeva, A. G., \& Abdykhalykova, "Developing Students'writing Skill In English Trough Creative Writing," Научные и творческие достижения в рамках современных образовательных стандартов, pp. 7-9, 2019.

[2] W. Hu et al., "Developmental dyslexia in Chinese and English populations: dissociating the effect of dyslexia from language differences," pp. 1694-1706, 2010.

[3] X. Tong, X. Tong, and C. Mcbride, "Radical sensitivity is the key to understanding Chinese character acquisition in children," Read. Writ., 2017.

[4] A. Lee, C. D., \& Spratley, Reading in the Disciplines: The Challenges of Adolescent Literacy. Final Report from Carnegie Corporation of New York's Council on Advancing Adolescent Literacy. New York: Carnegie Corporation, 2010.

[5] A. E. Study, "Local Wisdom in Javanese Language and Culture expressed by the Javanese Coastal Community of Banjar Kemuning Village of Sidoarjo," Taiwan J. TESOL, vol. 338, no. Prasasti, pp. 303-307, 2019.

[6] D. R. Meisani, "Responses towards Policy on TEYL in Elementary Schools :," vol. 254, no. 060, pp. 140-144, 2019.

[7] M. Chen, "PHRASAL PARAPHRASE LEARNING," Taiwan J. TESOL, vol. 16, no. 1, pp. 41-66, 2019.

[8] L. Benade, "Flexible Learning Spaces : Inclusive by Design ?," New Zeal. J. Educ. Stud., no. 0123456789, 2019.

[9] J. Chen and P. A. Kirschner, "The Role of Collaboration , Computer Use , Learning Environments , and Supporting Strategies in CSCL : A Meta-Analysis,” vol. XX, no. X, pp. 1-45, 2018.

[10] M. E. Babikir and I. Salim, "Exploring Problems Facing Second-Year Secondary 
Students in Paragraph Writing," vol. 5, no. 5, pp. 2015-2017, 2016.

[11] S. Mousavian and H. Siahpoosh, "International Journal of Applied Linguistics \& English Literature The Effects of Vocabulary Pre-teaching and Pre-questioning on Intermediate Iranian EFL Learners ' Reading Comprehenstion Ability," no. c, pp. 5863, 2018.

[12] T. H. Puertas, "Teacher' s feedback vs . computer -generated feedback: A focus on articles," vol. 10, no. 1, pp. 67-88, 2018.

[13] O. Cristina, F. Josep, D. Mariona, and G. Climent, "Teaching a Phonological Awareness Skill With the Time-Delay System in a Mainstream Setting: A SingleSubject Research Study Teaching a Phonological Awareness Skill With the TimeDelay," Read. Writ. Q., vol. 0, no. 0, pp. 1-13, 2018.

[14] S. Y. Han and Y. H. Choi, "Post-Reading Question-Generation Activities and Cooperative Learning in EFL Reading," vol. 73, no. 2, pp. 37-58, 2018.

[15] G. G. Kaca, "Influences of Instructional Policies on Novice Teacher Cognition : Help or a Hindrance ?," vol. 42, no. 9, 2017.

[16] K. Saddhono and M. Rohmadi, "A Sociolinguistics Study on the Use of the Javanese Language in the Learning Process in Primary Schools in Surakarta, Central Java, Indonesia." Int. Edu. Stu., vol. 7 no.6 pp 25-30, 2014 